\title{
Cross-Cultural Filmmaking as a Process of Self-Reflection: Filming Native Americans within Central European Space's Prevailing Imagery of the "Noble Savage"
}

\author{
LÍVIA ŠAVELKOVÁ \\ Department of Social and Cultural Anthropology \\ University of Pardubice, Pardubice, Czech Republic \\ livia.savelkova@upce.cz
}

\begin{abstract}
In Said's notion of "Orientalism" as a set of discursive practices through which the West structured the imagined East, the Czech Republic (or former Czechoslovakia) in particular, and so called Eastern Europe in general, has been viewed by "the West" as a space inhabited by "exotic other". The former socialist countries (and the so called post-socialist countries) have been constructing their own "Orients" and "exotic others" as well including Noble Savage stereotype of Native Americans. This paper focuses on a visual (re)presentation of a meeting between people who might have mutually constructed each other as the "exotic other". Based on filming of a visit of a Native American sport team competing in the Czech Republic, the paper would like to discuss who are the "exotic ones" and for whom and the methodological issues related to the creation of the cross-cultural ethnographic films.
\end{abstract}

KEY WORDS: Visual representation, ethnographic film, post-socialism, Native Americans, political correctness, Noble Savage stereotype, reflexivity 
I am sitting in a living room on the couch and watching the movie with elder Haudenosaunee (in the Czech Republic still known more as the Iroquois) ladies. The Mohawk (one of the Haudenosaunee nations) $17^{\text {th }}$ century warriors just attacked the Algonquian group accompanying one Jesuit missionary and killed most of the group (not the priest). With sex scenes supporting the image of the naturalism of the environment of that time I wish not to be in a room with ladies. I am feeling really ashamed. I am upset with myself that I had not watch it before I recommended to see it with my Native American friends and just accepted my Czech friends' opinions that this movie was a great film. The ladies are silent, tension breaks with the Mohawk words "they drank" sounded in a film and Haudenousaunee women start to laugh. It was my first opportunity to watch the film Black Robe (1991), a movie that gained Genie Award in Canada.

The event described above took place in 2001 and it was also my first "direct" experience with cross-cultural visual representation and at that time I had no idea that in few years I would be solving the issue of cross-cultural representation with my own filmmaking. This paper focuses on the issue of representation in general, on the issue of representation of North Native Americans, and, particularly, on the representation of a specific group in the Czech Republic. The issue of representation is formulated through our experience of the filmmaking that was realized between 2011 and 2014 with my colleagues Tomáš Petráň (The Film and TV School of The Academy of Performing Arts in Prague and The Institute of Film-Film Academy Ohrid - associate member of the Goce Delčev University of Štip in Macedonia) and Milan Durňak (The Department of Ethnology at The Charles University in Prague and The Department of Social and Cultural Anthropology at The University of Pardubice in Pardubice).

The question of cross-cultural or transcultural filmmaking has been discussed mainly within the context of the relation between Western filmmakers and anthropologists and the "exotic" colonized "other" (WORTH - ADAIR 1972; BELLMAN - JULES-ROSETTE 1977; WEINBERGER 1992; TURNER 1992; GINSBURG 1995; RONY 1996; BARBASH - TAYLOR 1997; MacDOUGALL 1998; RUBY 2000; REKHARI 2008; WILSON - STEWART 2008; MARCUS - RUBY 2011; PETERSON 2013). This debate generally lacks the experience from the so-called post-socialist countries and is only slowly making its way into the discourse in Western academia (DIATCHKOVA 2008; SIKORA 2012; ARZYUTOV 2016; KUBICA-HELLER 2016). 
The focus of this paper, the experience of my colleagues and myself during our filming of Lacrosse - It's a Way of Life $e^{1}$ was not certainly planned as a "case study" of the issue of cross-cultural filmmaking. But the whole process brought up questions and issues we had to address and that eventually led to this article. Given the personal character of some topics, I had to consider the ethical aspects of this presentation. ${ }^{2}$ I hope that the presentation of these issues and questions here will not harm anyone and will lead to a better understanding of the many perspectives and expectations of the participants who were involved in the creation of the film. Further, I hope it will engender the necessary discussion, which could be helpful to future cross-cultural filmmaking, especially between indigenous peoples and people from Central Europe and the so-called Eastern Europe (mostly post-socialist countries), where the stereotype of the Noble Savage is still prevalent. It can show that although first-hand mutual sympathetic approaches between the Native Americans and nations from the so called Eastern Europe may be present due to their experiences with the colonialism and oppression, at the same time potential communicational misunderstandings may appear specifically because of these historical and regional forms of colonialism. This article hopes to give insights to these issues and engender a further discussion of these potentially conflicting areas. I would like to suggest that these are not insurmountable if mutual respect is present.

\section{Filming in and with a team}

In 2011, the World Indoor Lacrosse Championship was held in Prague, Czech Republic. Native Americans were represented by the Iroquois Nationals, a team of the Haudenosaunee or Iroquois Confederacy. The championship is held once in four years and is organized by The Federation of International Lacrosse (FIL). This organization is the only international sport organization that recognizes a Native American team. The Iroquois Nationals started participating in the championship in the 1990s, after a hundred years

The film Lacrosse - It's a Way of Life (Cinepoint 2014) is bilingual with the Czech-English subtitles, 63 minutes long.

2 To the ethics see for example RYNKIEWICH - SPRADLEY 1976; HEIDER 1976, 2006; MIHESUAH 1993; SMITH 1999; FLUEHR-LOBBAN 2003; LASSITER 2005. In the Czech and Slovak languages see two issues of journals focused on this subject: Biograf 2004:35 and Národopisný věstník 2014:2.

DOI: 10.1515/eas-2017-0012 C University of SS. Cyril and Methodius in Trnava. All rights reserved. 
hiatus. Their participation is a way to express political sovereignty of the Haudenosaunee in particular and indigenous peoples in general. ${ }^{3}$

It was a great honor for the Czech lacrosse community and Native American supporters, including me, to welcome the Iroquois Nationals to the Czech Republic. I have had contacts with the Haudenosaunee since 2001, when I first came to their territories. Thanks to these personal contacts I was able to obtain permission to film their visit. The team had their own film makers with them to document their stay.

I asked a colleague and a former student of mine to join me and to film. My personal role was different from that of my colleagues. Partly, I was a voluntary "home liaison," in charge of organizing transfers from hotel to practices and tournaments, hospitals (when necessary), translations and any other matters that needed to be arranged. Unlike me, my colleagues were not in the position of the "home liaison" and thus were able to follow the team and continue filming, even when I had to go and solve logistical problems. Sometimes it was me who was focusing the camera on particular action, sometimes not. This led to different perspectives and experiences with the filming process. Gender also played a role, as my male colleagues were able to follow the team to spaces I could not as a woman, for example the men's locker room, without breaking the atmosphere of the moment.

The filming was influenced by many diverse issues and challenges, including technical ones, but most importantly those related to the meeting of different cultures and the varied expectations and perceptions of the "others". Our professional backgrounds (as ethnologists, anthropologists, journalists and documentary filmmakers) influenced our approach as well as personal experience with the process. So did the relations between those in front and behind the camera. Having two cameras at times also meant that some of the "filming crew" sometimes appeared in the front of the camera.

Diverse ideas of and discussions about ethical representation also influenced our experience and the final product. We continued these conversations and more filming in the following years, which focused on the question of the meaning of lacrosse for Native Americans, but also for Czech lacrosse players. The final film offers these ideas to the audience to ponder. It is also a representation of the Haudenosaunee relation with the "game", but also of the Czech lacrosse players' perception of the game's Native origin.

3 To specific histories, meanings and importance of the lacrosse for various communities and players see for example VENNUM 1994; FISHER 2002; CALDER - FLETCHER 2011; DOWNEY 2012; ŠAVELKOVÁ 2017.

DOI: 10.1515/eas-2017-0012 C University of SS. Cyril and Methodius in Trnava. All rights reserved. 


\section{When the "Exotic Others" Meet}

Our film is based on a team work and during editing of the film several important questions appeared and reflected habitus and various focuses of all of us involved in all stages of filming. Having in mind polemics related to the crisis of representation famously discussed and developed by anthropologists and other scholars, such as HYMES 1974; FABIAN 1983; CLIFFORD - MARCUS 1986; MARCUS - FISCHER 1986; CLIFFORD 1988; ROSALDO 1989; and of course by Native American scholars such as DELORIA Jr. 1969; McNICKLE 1970; or MEDICINE 2001, in relation to the Native Americans lately developed by CLIFTON 1990; VIZENOR 1993; FARIS 1996; MIHESUAH 1996; CHURCHILL 1998; KILPATRICK 1999; HUHNDORF 2001; PRINS 2002; STRONG 2004, 2012, the most important issue for us was to think about the audiences. This theme appeared as the topic during the editing process and film pre-screening for various audiences. Spending hours closed in editing room, including having a baby with us, having no funding for our work we had to ask all the time: For whom this film was made? Potential different expectations of various audiences at different parts of the world and of social background with their possible ways of seeing (MARTINEZ 1992; BANKS 1996; RUBY 1998; MacDOUGALL 1998; HUGHES 2011) meant a difficult decision making and therefore opened the most important questions related to methodological and ethical issues. How do we represent the groups, such as the members of the Haudenosaunee sport organization and the Czech lacrosse players? What are their expectations about the final product and process of the finalization of the film? To the analysis of this situation, we found useful Rosaldo's concept of positionality (ROSALDO 1989, 1993) dealing with various methodological issues reflecting the anthropologist as a positioned subject.

The most interesting questions for me came with the notion of what happens when the visual (re)presentation is discussed by people who might have been mutually constructed as the "exotic other". In Said's notion of "Orientalism" as a set of discursive practices through which the West structured the imagined East, "even" the Czech Republic (or former Czechoslovakia) in particular, and the so-called Eastern Europe in general, has been viewed 
by "the West" as a space inhabited by "exotic other" (SAID 1978; WOLFF 1994). ${ }^{4}$ The former socialist countries and the so called post-socialist countries (WOLFE 2000; HANN 2002, KÜRTI - SKALNÍK 2009) have been constructing their own "Orients" and "exotic others" as well. As Todorova stated: "Everyone has had one's own Orient, pertaining to space and time, most often of both (TODOROVA 1997:12)." How do we reflect this concept in our work?

The participants in our film came from different backgrounds, even worlds that have both constructed the image of the "other," which was often stereotypical. The Czech lacrosse players (especially the older generations) were influenced for decades by movies based on Karl May's books about the "noble savage" Apache leader Vinnetou. ${ }^{5}$ This portrayal was in a contrast to the stereotypical Hollywood image of the Cruel Savage that dominated the movie industry prior to the 1990s (with the exception of movies such as Little Big Man) (WEATHERFORD 1981; CHURCHILL 1998; KILPATRICK 1999; ALEISS 2005; RAHEJA 2010). Native American lacrosse players were similarly influenced by the American stereotypical representation of the "exoticized" Eastern Europe and the Socialist Bloc.

As a filmmaker "crew" coming from the former Eastern Bloc, we had been influenced by the Noble Savage stereotype ourselves; something we had to address and consider. This fact stimulated my thought and prompted a further reflection and search for answers to the questions: Who is the "exotic other"? And from whose perspective? How does the awareness about different audiences (with their possible specific stereotypes about the "exotic others") affect the final product of filmmakers and anthropologists? What are the ethical issues involved in decision making and knowledge production by "Non-Western" people about marginalized peoples in the West?

$4 \quad$ I remember having at home in the 1990s an exchange student from the former Western Germany being surprised we had some toothbrushes. I could add a lot of similar stories when I stayed in England and France during the 1990s.

$5 \quad$ These films were made since the 1960s by director Harald Reinl. One of his films was translated to the Czech language as Vinnetou - The Red Gentleman/Vinnetou - rudý gentleman (1964) with the premiere in Czechoslovakia in 1965. To the specific and nationalistic presentations of the Native American in various European countries see FEEST 1990, 2011; CALLOWAY GEMÜNDEN - SUSANNE 2002; LUTZ 2015.

DOI: 10.1515/eas-2017-0012 C University of SS. Cyril and Methodius in Trnava. All rights reserved. 


\section{Promotion of lacrosse, sovereignty and self-representation}

An attempt to find at least some replies to previously opened questions would mean to mention different backgrounds and potential stereotype-based expectations. Based on my experiences from stays in the U. S., Canada ${ }^{6}$ and on the Haudenosaunee territories or reservations, I would say there has been very important factor in perception of Native Americans in the U. S. and Canada by the dominant American and Canadian society and of the anthropologists that is in a social stratification. Native Americans are socioeconomically on the lowest levels of society in the U. S. and Canada and anthropologists famously criticized by Deloria Jr. (1969) are considered to be the representatives of the middle class. We as "a filmmaker crew" might not fit in the expectation of some of the Native people. Being regular academics in the Czech Republic (in a position of assistant professor) means that for years we would get under average salary. Political transformation following the end of the communism in 1989 did not of course change the society to mirror the social stratification of the so called West. In the communist times the manual work was highly appreciated and intelligentsia (especially of social sciences and humanities) was persecuted and considered to be dangerous to the state doctrine. Our generations born in the 1970s and earlier have grown in times when it was common that working class people were meeting with and living at the same apartment complexes with highly educated people. People who were considered dangerous to the regime could not study at the universities and had to work at the worker's positions. They were usually highly educated through underground seminars and "illegal" networks. The misuse of the state power also resulted in a resistance to the official authorities. Although the attitudes might be of course more varied, this description can give some idea that we used to grow in a society of different social background compared to that in the U. S. or Canada. Therefore by our clothing, acting, communicating we definitively did not fit to possible expected social status of "western" academics. The team Iroquois Nationals lived in the hotel Hilton where we could not afford to eat with them. But they were very hospitable and invited us for a meal and an official dinner out.

Another example of the difference between some of the Native sportsmen's initial view of us and our reality was the fact that we were producing a film without any funding. Our generation born in the 1970s and educated at universities in the 1990s (and at the turn of the

Simon Fraser University in 2004-2005.

DOI: 10.1515/eas-2017-0012 C University of SS. Cyril and Methodius in Trnava. All rights reserved. 
century) has grown up on having very little sources of information due to the lack of access to the western science journals, books, etc. Without today's digital technologies and with an unfavorable exchange rate of that time it was difficult to obtain informational sources from the West, specifically information on Native Americans from the U. S. or Canada. But our enthusiasm lead to the deep collaboration and sharing among groups of people interested in particular activities, although without sufficient economical sources. It also resulted in a specific approach to "copyrights" among many people that is also tied with the previous illegal sharing of prints during the communist times. So our knowledge and practice of teamwork has been very different than that of the U. S. highly competitive academic environment with an individual anthropologist doing his or her research supported by grants. $^{7}$

So at the time of making the film, we may have been seen "exotic" in terms of the expectations based on the capitalist or neoliberal society's views in which Native Americans live, criticize and at the same time very often accept.

Although being aware of cautious ways of naming and representing strategies and its importance in the U. S., we were not so much relying on it which may have been confusing for the Iroquois Nationals members and American public as well. Social situation played an important role - they were visiting the Czech Republic and partly ready for different form of communication. Our use of English was also important. Those who have been in the U. S. or Canada very often ridiculed for their English language skills were with us at the position of excellent Native English speakers. Further, we were very often terribly tired due to the lack of sleep that stressed our "broken English". Important to add is the fact that we were all tired from a busy and emotionally demanding tournament's week.

The representing strategies, with their various usages in different parts of the world became a "hot" and from our perspective unexpected issue in our final editing. We felt important to give a chance to all participants to comment on the version of the film before making the final edits. Therefore, we have pre-screened our version to the Czech participants at the end of the year 2013 and to some Haudenosaunee in April 2014 when they came to the Czech Republic again. Further, we pre-screened the film to students of sociology and anthropology at the Faculty of Social Sciences of Charles University at the end of the year

\footnotetext{
During the last years I have also obtained a grant from the Czech Science Agency that did not cover the first film but helped to cover partly our second bilingual film about lacrosse - The Global Lacrosse Village (2015, $83 \mathrm{~min}$ ). Available on-line at: http://kska.upce.cz/veda-zabava/globalnilakrosova-vesnice-global-lacrosse-village/.
}

DOI: 10.1515/eas-2017-0012 C University of SS. Cyril and Methodius in Trnava. All rights reserved. 
2014. The issues these groups focused on were very different. The Haudenosaunee viewers liked it and laughed during the film, similarly to the Czech lacrosse players. The Czechs discussed more the possible role of the film in promotion of lacrosse in the Czech Republic (where it is still less known sport aside of additional camping activities and the specific Czech lacrosse form played with a stick in one hand), while the Haudenosaunee stressed more the self-representation, kinship, and sovereignty aspects. The students showed different generational look - most of them did not know lacrosse (compared to our generation born in the 1970s for whom lacrosse was also the symbol of resistance ${ }^{8}$ ), a lot of them did not know about the woodcraft or boy and girl scouting. They paid attention to the sport of lacrosse as an adrenalin activity and to the use of the film at the extreme sport festivals.

The Czech lacrosse participants had no attempt to change anything in the film which was different from the Haudenosaunee. Personally I was deeply interested in the reaction and acceptance of the Haudenosaunee participants of the film because I have a deep respect for them and my friendship with them is important to me. I have chosen different members of the team from different reservations, urban areas, nations and I asked them about their perception of the film. Although they laughed during the pre-screening, they also expressed concerns about representation of Native players in the film with regard to the potential reception from traditional elders. One official representative mentioned that there were "just three small things" he would suggest we might to think about changing. These were scenes including drinking beer on a boat, a coaches cursing during a tournament, and a shot of an injured goalie leaving the field during the final game. I was told that: "everybody knows that it is like this, but elders do not want to see it..." Another young traditionalist mentioned the same thing and told me if we left it there it might happen that elders would not let me come back to the reservation. The official representative suggested to make two versions of the film - a European and American, and asked me not to put the European version on the internet. I have replied that we would think about these scenes that were problematic for them, but that the suggested cuts may be seen as "censorship" by some of us.

These issues presented a huge dilemma for me and the film crew. My role was definitively different, because my friends and colleagues didn't have the personal friendships that I have had years with people on reservations. Similarly, my colleagues did not focus on

8 About the history of the lacrosse in the former Czechoslovakia see ŠAVELKOVÁ 2017.

DOI: 10.1515/eas-2017-0012 C University of SS. Cyril and Methodius in Trnava. All rights reserved. 
Native Americans and their issues as subject studies. Further, they were not aware of the self-representation discourse in the context of settler colonialism that has developed in the U. S. and Canada.

This issue engendered many conversations and polemics about the notion of different historical experiences, perceptions, and understandings. It took us back to the questions of audiences and representation of the "other". Our film is not only about "them" but also about "us", about the Native players as well as the Czech lacrosse players and the filmmakers as well. The questions we asked ourselves were numerous and challenging: How should we deal with the various historical experiences with colonialism? How to respectfully deal with sensitivity with particular approaches and meanings?

The identity politics and cautious naming strategies are deeply present in all Native American affairs that have not been a part of the discourse in the Czech Republic. The "postcolonial" discourse includes very often a notion of one homogenous group of white Euro-American colonizers without deeper understanding of differences of European nations. ${ }^{9}$ But the experience with the oppression was an important factor during the emergence of and spread of nationalism during the $19^{\text {th }}$ century leading to later creation of the "nation-states." It has been an important discourse within a lot of countries of Central Europe. Compared to Native American experience with colonization and subjugation, in the case of the Czechs, their "oppressors" have changed during the last century. The Czechs have deep experiences with various forms of subjugations: 1. Austrian Habsburg monarchy with its German speaking inhabitants being on the top of hierarchy until the end of the First World War, 2. after 20 years of independent statehood after the First World War and Munich agreement from 1938 came the Nazi occupation, 3. few years after the Second World War the socialist regime with Russian influence and the final 1968 invasion of Warsaw Pact troops army and a Soviet occupation till 1989. Living under state propaganda and making jokes about it at the same time, having nearly no access to information from the "outside", and no freedom of speech, created specific form of communication including hiding real meanings, development of poetry, underground and grassroots activities including copying and sharing of translations of the literature from the so called West.

$9 \quad$ At one conference, I have experienced very unpleasant verbal attack on one Polish colleague who was discussing genocide and was totally misunderstood by one Native American scholar who had had no idea about the Polish history with its huge violent population loss during the Second World War.

DOI: 10.1515/eas-2017-0012 C University of SS. Cyril and Methodius in Trnava. All rights reserved. 
Native Americans are sensitive to representation of them by Non-Natives, as some generations of the Czechs are highly sensitive to censorship, propaganda and spontaneous creativity of an artist. These sensitivities are due to the specific colonial experiences. Although these conditions may be significant for the various interpretations and quite opposite in some way, these experiences have one important and "similar" factor involving mutual solidarity - and that is humor: black, heavy and ironic. ${ }^{10}$ Humor has been a common survival tool for groups and people dealing with the various forms of colonialism.

The most interesting and also discussed theme among us as filmmakers was dealing with a Nation building ideology. We saw parallel between the Czech National Revival of the late eighteenth and the nineteenth centuries and Native American revitalizations, in our case of the Haudenosaunee. Sport played a role in the Czech National Revival as a vehicle for revitalization, represented by the organization Sokol. Similarly, lacrosse has functioned as a tool for the contemporary Haudenosaunee revitalization. This parallel fascinated us. At the same time, we were aware of a possible propaganda that is very often tied with a nation building ideology and to that we wanted to avoid.

These differences and parallels and expectations of different audiences influenced our debates and final decisions about the film editing. We wanted to be fair to the Haudenosaunee, but at the same time to other viewers as well. The famous polemics between D'Andrade and Scheper-Hughes (1995) about moral models in anthropology came out on our discussions. I have discussed this issue with many of my colleagues among ethnologists, anthropologists and also among my friends who have connections to Native communities and often spend time on reservations. We could not make two versions of the film for various audiences, although it would have been a solution. Although it could be great to have a chance to discuss these various perspectives personally with many Haudenosaunee people, it was not possible. Because of economical (we had no resources) and family reasons (I had my second son) we as filmmakers had no chance to travel overseas. Therefore, we communicated via email and mail correspondence. Although we were not pushed by any project or grant deadlines and we have made additional filming since 2011, a colleague's editing computer was often collapsing and he needed to start to work on it with another - at this time paid job. That meant we needed to make a decision

10 The specifics of the conceptualization of the humour related to the Native Americans in the former Czechoslovakia was presented at the American Indian Workshop in Odense in 2016 in collaboration with Klára Perlíková from the Department of Ethnology, Charles University in Prague (forthcomig).

DOI: 10.1515/eas-2017-0012 C University of SS. Cyril and Methodius in Trnava. All rights reserved. 
about the film editing and finish it. Important to add, three of us were debating and discussing in respect to each one's perspective.

An important help in our decision-making process came from an informal screening for Native American scholars at the 2014 American Indian Workshop conference. There were Haudenosaunee representatives in the audience as well. They all liked it and had no problems with any of the scenes in the film. It is important to point out that these were Native academics with different expectations and approaches than those of other Native peoples and their various cultural backgrounds and cosmologies. At the same time young Native artists commented on the potential expectations of elders: "You know, people are very often afraid, what elders would say, but if they knew what elders had done while being young..."

Finally, we reflected on the various audiences and our responsibilities to the Native participants and came to a final decision:

First, due to the stereotype of the "drunken Indian" in the U. S. and Canada we cut out the scene with the beer on a boat. In the Czech Republic, there is no prohibition and it is normal to drink a beer (not to get drunk but just for its taste and in combination with the Czech heavy meal), it is a common and everyday life-habit that nobody would give any significance to. As my older editing colleague pointed out, "I would feel it really weird if tourists would be drinking a soda on a cruise instead of beer." That means that to the Czech viewer to see the Native American with a beer does not evoke an image of the "alcoholic Indian" that is the case in America. Second, after a personal discussion with a goalie and reflection of traditionalist's cosmology we also cut out the scene with the injured goalie. The problem of the goalie was in a magic that may bring another health trouble to him.

The third was the coursing coaches. This was probably the most problematic decision to make. Finally, we have reflected on the composition of the scene in terms of relation to the notion of the Noble Savage and favored the European audience and cultural background of this part of the world and kept the scene in the film. In this part we were also making fun of us by focusing on the Noble Savage imagination strongly present in our minds and at the same time we were showing that emotions are part of the sport. In fact, we believed that the humor in this scene would be understood across cultural lines and would not cause any harm to Native peoples "overseas."

Further, we made a version for the Native elders without this scene. They have both, the official film and the "fully cut-out version" and they can decide which one they would like 
to screen to their young ones. In 2015, we could finally get to the Haudenosaunee personally, this time filming the Czech lacrosse team at the World Indoor Lacrosse Championship organized that year at the Haudenosaunee territory. We asked some official representatives and we were told the film was OK. One person mentioned that he had no time to see it yet. I am very grateful my friends who had a patience with me and who were willing to make steps aside to cut off scenes that Haudenosaunee representatives were asking to change although it might seem to my colleagues as unimportant or narratively damaging step.

\section{Lacrosse in a documentary}

The form of our film may have influenced the different understandings by the diverse audience - American, Canadian, and Native American who are used to TV documentaries as well. It was clear from comments of some of the Native representatives. We were asked if we saw the documentary made by their filmmakers who came to film their presence at the World Indoor Lacrosse Championship of 2011 in Prague and we were told that it was well accepted by the public. ${ }^{11}$ This film, just as recent "documentary" films about Native Americans in general, and about lacrosse in particular, is very different from our film in a form of more easily understood perspective through its narrative structure. Further, the favored form in the U. S. is the docudrama, which includes act-out scenes (enacted scenes) to represent the discussed events. Our film also differs in a structure from recent documentaries about lacrosse produced by academics and students in the U. S., such as Sacred Stick, ${ }^{12}$ America's First sport, ${ }^{13}$ Stickmaker, ${ }^{14}$ or Medicine Game. ${ }^{15}$ These films cover Native Americans' interpretations of the meaning of lacrosse in the past and present and of contemporary lacrosse players' and officials' opinions what we also did. But these

11 The Creator's Game: The Quest for Gold and the Fight for Nationhood (2011), director and producer: Candace Maracle, $42 \mathrm{~min}$

12 Sacred stick (2013), director: Michelle Danforth with co-producer Patty Loew, and co-production of Wisconsin Public Television \& Vision Maker Media, $57 \mathrm{~min}$.

13 America's First Sport (2013), director: Dennis Deninger, 57 min, Syracuse University.

14 Alfred Jacques, Onondaga stick maker. The Stickmaker - Alf Jaques "Unstrung" Handmakes Wood Lacrosse Sticks, <http://www.youtube.com/watch?v=iSoR9oGGpOc>, accessed 26th May 2014. Stickmaker. Directors: Curtis Albucher \& Kevin Lee, Assistant Producers: Dustin Dohm \& Justin Skaggs.

15 Medicine Game (2013), director: Lukas Corver with co-producer Jason Halpin, 68 min.

DOI: 10.1515/eas-2017-0012 C University of SS. Cyril and Methodius in Trnava. All rights reserved. 
films stress one- dimensional educational perspective for broader American audiences without an attempt to push viewers to think about various ideas including the filmmaker's subjectivity and his or her interaction with the people being filmed. Given our attempt at an ethnographic (or anthropologically) intended film in terms of Ruby (RUBY 2000:6) we wanted to be fair and transparent in showing our involvement and reflexivity in the whole process. Our involvement and inclusion in the final product could be seen by some as the filmmakers "showing off" or search for the lime light, but that was not our purpose. Personally, I did not want to be included in the footage, playing Czech lacrosse, but my colleagues thought it would add to the overall value to the film as it would better demonstrate the depth and the meaning of lacrosse to us. Since those were the topics and themes we wanted to demonstrate - the meanings and depth of the relation to lacrosse of the various people and players, demonstrating our own relation to and involvement with lacrosse seemed honest. ${ }^{16}$

\section{Representation in cross-cultural spaces}

Additional questions regarding ethics and scholars' and friendship's responsibilities came from the process of producing our film. For example we had to ponder questions such as: How to act correctly if there is no reply from participants for months? What to do if the official representation is not homogenous in its reaction and how to react when internal politics is involved? How to deal with the power that we, as filmmakers, anthropologists or ethnologists have, giving the film its final form?

Ruby asks: "How can the anthropologist justify his or her representation of another culture when the representation differs from the self-image of that group" (RUBY 2000:138)? Our experience shows that there is no simple answer to this question. It would be easy if there was a single self-image within a given group, but that is usually not the case. The Native lacrosse players and their communities represent various self-images within their respective groups, the same as each individual has his own opinion. Given the nature of the filming and production process, the final film does not address all the important topics and issues related to contemporary Native America. Some issues came out in our informal conversations with the players, such as questions of identity or financial sponsorship of the

${ }^{16}$ To our surprise, also people participating on postproduction (or their family members) were former players of lacrosse and members of the lacrosse community.

DOI: 10.1515/eas-2017-0012 C University of SS. Cyril and Methodius in Trnava. All rights reserved. 
team, but they were not part of the official filming. The identity politics in the U. S. and Canada with U. S. "obsession" with race, blood quantum and full-bloodiness in the case of Native Americans in general, is very different that of the Czechs. ${ }^{17}$ With the exception of the last few years and the influence of the refugee and immigration crisis, race and identity have not been a dominant discourse in the Czech Republic. That is not to say that it is not a present issue. However, compare to the U. S. and Canada, it is relatively limited.

The filming experience also complicates "Western" understanding of the construction and representation of identities by minorities. Scholarly understanding of this phenomenon is often within the context of binary opposition of power relations between the dominant and marginalized societies. According to Buchowski, "resistance to dominating images and practices becomes a significant factor in the reconstruction of identity of those who are constructed by those in control" (BUCHOWSKI 2006:474). However, our experience with the filmmaking process suggests that when representation and self-representation of identities enter a different cultural space with specific forms of communication and perception these balances of power no longer apply. But I do not want to deny that the final film product will be always a subject of negotiation, very often with a great power of the director or directors although with his or her attempt for participation or collaboration of those who were involved.

Political and propaganda strategies of the U. S. and USSR during the Cold War also used images of Native Americans reflecting power relations in mainstream media. The communist regimes with their propaganda images of the indigenous peoples suffering under the capitalist oppressors (see for example TOTH 2016 KÝROVÁ 2017), with their specific mediascape (APPADURAI 1990) and specific historical experiences with oppression of the population in the former Czechoslovakia, led to the primarily sympathetic attitudes towards the indigenous peoples in general, and to Native Americans in particular. In the Czech Republic, it is still challenge to present the contemporary Native Americans here in a different form than that of the Noble Savage to a wider population.

Although the ethnographic or anthropological films are not constructed to be widely and easily understood by mass audiences, they will always present a challenge to local and

17 The "tabu" over Native American Identity rules and disputes has been provoked by young Native Americans during the last years, such as the 1491s'. See for example: Blood Quantum Leap: <https://www.youtube.com/watch?v=BlyKn3rpERs> accessed 9th September 2017, published in 2011. 
global audiences and their stereotypical views (GRIMSHAW 2001). There are more ways of seeing our film than I have described in this text. With each screening of our film to different audiences we can see various reactions that are also influenced by its bilingual character and the use of the Czech-English subtitles. The translation as a transmission of meanings was very important and complicated issue as well during the filmmaking process. We attempted to keep the translations (subtitles) as close to the original meanings and speech patterns of the participants as possible. At the same time we had to synchronize the subtitles with the video with the potential varying speed of reading of various audiences.

Anyone planning to work on indigenous issues with people from the former British Empire who have experienced settler-colonialism should be aware that they will deal with negotiations over the representation and self-image of the group. That is understandable, given the situations of indigenous peoples, but very often different to the history and practice of the documentary filmmaking in this part of the world. Although Kilpatrick writes primarily about Hollywood feature films, her comments could be useful to all documentarists or ethnographic filmmakers from Central Europe. "It must seem to filmmakers telling a story about Indians that they are damned if they do and damned if they don't. Tell a story about a mixed couple who cannot be together and live-it's racist. Tell the same story and let them live happily ever after - the love story becomes a deadly form of assimilation. Make the Indians good guys and you're producing the noble savage stereotype. Show the Indians being bloodthirsty and you likely to be shot by our own friends in Hollywood" (KILPATRICK 1999:179).

Although Kilpatrick suggests that the best solution is "not to make movies about Indians but let it made by themselves" (ibid) that is to give them a chance to represent their worldviews by themselves, I think there is no reason to give up a chance to go into the various perspectives of seeing the world. These "intercultural" encounters can be to some level unpleasant to some participants and filmmakers, but at the same time they can bridge the gap between people from different backgrounds and offer views about the universal humanity instead of focusing on "specific cultures" with their collective identity boundaries.

In our case, a lot of often cited examples of the disempowered characteristics related to "marginalized" groups were challenged. Personal and historical conditions reflected through our experiences of this filming process offered a shift in commonly discussed power relations between "Natives", "marginalized", "exotic other" and anthropologists (or filmmakers). Economic status, language skills, form of communication and behavior, 
mutual imagination of the other are just few examples of various significances in various epistemologies dealing with the concept of power.

It would be interesting to obtain more information about experiences of filmmaking by the "exoticised" about the "exoticised" and their dealing with ethical and methodological issues. It might bring a fresh view to our discipline that is still widely formed by the Western academics.

To finish up on a positive note, I am happy that we can still sit with some Native friends on the reservation or here in the Czech Republic and laugh together without thinking about the colors of our skin, ID status, or academic career. And making a film, although it could be challenging and even hurtful at times, has always been a great journey without a known end, the same as everybody's life is.

\section{Acknowledgments}

I would like to thank to all my colleagues and friends who helped to improve this paper by their comments, discussions led with me during the last years, filming with me, subtitling, and by proofreading of this text: Lucie Kýrová, Tomáš Petrán̆, Milan Durñak, Tereza Hyánková, Tomáš Samek, Martin Heřmanský, Klára Perliková, Jan F. Ullrich, Hana Synková and Tomáš Retka.

\section{Bibliography}

ALEISS, A. (2005): Making the white man's Indian: Native Americans and Hollywood movies. Westport, CT: Praeger.

APPADURAI, A. (1990): Disjuncture and difference in the global cultural economy. In. Theory, Culture and Society 7, pp. 295-310.

ARZYUTOV, D. V. (2016): Samoyedic Diary: Early Years of Visual Anthropology in the Soviet Arctic. In. Visual Anthropology 29, pp. 331-359.

BANKS, M. Which films are the ethnographic films? In. Peter lan Crawford, David Turton (eds): Film as Ethnography. Manchester: Manchester University Press, pp. 116-130.

DOI: 10.1515/eas-2017-0012 C University of SS. Cyril and Methodius in Trnava. All rights reserved. 
BANKS, M. - RUBY, J. (eds.) (2011): Made to be Seen: Perspectives on the History of Visual Anthropology. Chicago and London: University of Chicago Press.

BARBASH, I. - TAYLOR, L. (1997): Cross-Cultural Filmmaking: A Handbook for Making Documentary and Ethnographic Films and Video. Berkeley and Los Angeles: University of California Press.

BELLMAN, B. L. - JULES-ROSETTE, B. (1977): A paradigm for looking: cross-cultural research with visual media. Norwood: Ablex Publishing Corporation.

BUCHOWSKI, M. (2006): The Specter of Orientalism in Europe: From Exotic Other to Stigmatized Brother. In. Anthropological Quarterly 79: 3, pp. 463-482.

CALDER, J. - FLETCHER, R. (2011): Lacrosse: The Ancient Game. Toronto: Ancient Game Press.

CALLOWAY, C. G. - GEMÜNDEN, G. - SUSANNE, Z. (eds) (2002). Germans and Indians: Fantasies, Encounters, Projections. Lincoln and London: University of Nebraska Press.

CHURCHILL, W. (1998): Fantasies of the Master Race: Literature, Cinema, and the Colonization of American Indians. San Francisco: City Lights Books.

CLIFFORD, J. (1988): The Predicament of Culture. The Twentieth-Century Ethnography, Literature and Art. Cambridge: Harvard University Press.

CLIFFORD, J. - MARCUS, G. E. (eds.) (1986). Writing Culture: The Poetics and Politics of Ethnography. Berkeley: University of California Press.

CLIFTON, J. A. (ed) (1990): The Invented Indian: Cultural Fictions and Government Policies. New Brunswick: Transaction Publishers.

D'ANDRADE, R. G. (1995): Moral models in anthropology. In. Current Anthropology 36: 3, pp. 399-408.

DELORIA, V. (1969): Custer Died for Your Sins: An Indian Manifesto. New York: Macmillan.

DIATCHKOVA, G. (2008): Indigenous Media as an Important Resource for Russia's Indigenous Peoples. In. Pamela Wilson, Michelle Stewart (eds): Global Indigenous Media: Cultures, Poetics, and Politics. Durham and London: Duke University Press, pp. 214-231.

DOWNEY, A. (2012): Endendering Nationality: Haudenosaunee Tradition, Sport, and the Lines of Gender. In. Journal of the Canadian Historical Association/Revue de la Société historique du Canada 23: 1, pp. 319-354. 
FABIAN, J. (1983): Time and the Other. How Anthropology Makes Its Object. New York: Columbia University Press.

FARIS, J. C. (1996): Photographing the Navajo: Scanning Abuse. In. American Indian Culture and Research Journal 20:3, pp. 65-81.

FEEST, Ch. F. (1990, 2011): Europe's Indians. In: James A. Clifton (ed.): The Invented Indian: Cultural Fictions and Government Policies. 6th edition, New Brunswick and London: Transaction Publishers, pp. 313-332.

FISHER, D. M. (2002): Lacrosse: A History of the Game. Baltimore and London: The Johns Hopkins University Press.

FLUEHR-LOBBAN, C. (ed.) (2003): Ethics and the Profession of Anthropology: Dialogue for Ethically Conscious Practice. Lanham: Altamira Press.

GINSBURG, F. (1995): The Parallax Effect: The Impact of Aboriginal Media on Ethnographic Film. In. Visual Anthropology Review 11:2, pp. 64-76.

GRIMSHAW, A. (2001): The Ethnographer's Eye: Ways of Seeing in Modern Anthropology. Cambridge: Cambridge University Press.

HANN, Ch. (ed.) (2002): Postsocialism: Ideas, ideologies and practices in Eurasia. London and New York: Routledge.

HEIDER, K. G. (1976, 2006): Ethnographic Film: Revised Edition. Austin: University of Texas Press.

HUGHES, S. P. (2011): Anthropology and the Problem of Audience Reception. In. Marcus Banks, Jay Ruby (eds.): Made to be Seen: Perspectives on the History of Visual Anthropology. Chicago and London: University of Chicago Press.

HUHNDORF, S. M. (2001). Going Native: Indians in American cultural imagination. Ithaca, NY: Cornell University Press.

HYMES, D. (1974): Reinventing Anthropology. New York: Vintage.

KILPATRICK, J. (1999): Celluloid Indians: Native Americans and Film. Lincoln a London: University of Nebraska Press.

KNOPF, K. (2008): Decolonizing the Lens of Power: Indigenous Films in North America. Amsterdam: Editions Rodopi B. V.

KUBICA-HELLER, G. (2016): Fotografia etnograficzna dokumentująca życie Żydów w Polsce: charakterystyka ogólna/Ethnographic photography documenting Jewish life in Poland: an outline. In. Etnografia Nowa/New Ethnography 7-8, pp. 257-321. 
KÜRTI, L. - SKALNÍK, P. (2009): Postsocialist Europe: Anthropological Perspectives from Home. New York and Oxford: Bergahn Books.

KÝROVÁ, L. (2017): The Right to Think for Themselves': Native American Intellectual Sovereignty and Internationalism during the Cold War, 1950-1989. Ph.D. Dissertation, The College of William and Mary.

LASSITER, L. E. (2005): The Chicago Guide to Collaborative Ethnography. Chicago and London: The University of Chicago Press.

LUTZ, H. (2015): Contemporary Achievements: Contextualizing Canadian Aboriginal Literatures. Augsburg: Wißner, 2015. Studies in Anglophone Literatures and Cultures (SALC), 6 .

MacDOUGALL, D. (1998): Transcultural Cinema. Princeton: Princeton University Press.

MARCUS, G. E. - FISCHER, M. M. J. (1986): Anthropology as Cultural Critique: An Experimental Moment in the Human Sciences. Chicago: Chicago University Press.

MARTINEZ, W. (1992): Who Constructs Anthropological Knowledge? Toward a Theory of Ethnographic Film Spectatorship. In. Peter lan Crawford, David Turton (eds): Film as Ethnography. Manchester: Manchester University Press, pp. 131-161.

McNICKLE, D. (1970): American Indians Who Never Were. In. Indian Historian 3: 3, pp. 4-7.

MEDICINE, B. (2001): Learning to Be an Anthropologist and Remaining "Native" Selected Writings. Edited with Sue-Ellen Jacobs. Urbana and Chicago: University of Illinois Press.

MIHESUAH, D. A. (1993). Suggested Guidelines for Institutions with Scholars who Conduct Research on American Indians. In. American Indian Culture and Research Journal 17:3, pp. 131-139.

MIHESUAH, D. A. (1996): American Indians: Stereotypes and Realities. Atlanta: Clarity.

MICHAELS, E. (1986). The Aboriginal Invention of Television in Central Australia, 1982-1986. Canberra: Canberra Australian Institute of Aboriginal Studies.

PETERSON, L. C. (2013): Reclaiming Diné Film: Visual Sovereignty and the Return of Navajo Film Themselves. In. Visual Anthropology Review 29:1, pp. 29-41.

PRINS, H. E. L. (2002): Visual Media and the Primitivist Perplex: Colonial Fantasies and Indigenous Imagination in North America. In. Faye Ginsburg, Lila Abu-Lughod, 
Brian Larkin: Media Worlds: Anthropology on New Terrain. Berkeley: University of California Press, pp. 58-74.

RAHEJA, M. H. (2010): Reservation Reelism: Redfacing, Visual Sovereignty, and Representations of Native Americans in Film. Lincoln and London: University of Nebraska Press.

REKHARI, S. (2008): The "other" in film: exclusions of Aboriginal identity from Australian cinema. In. Visual Anthropology 21, 2, pp. 125-135.

RONY, F. T. (1996): The Third Eye: Race, Cinema, and Ethnographic Spectacle. USA: Duke University Press.

ROSALDO, R. (1989, 1993): Culture and Truth: The Remaking of Social Analysis. With a new introduction. Boston: Beacon Press.

RUBY, J. (2000): Picturing Culture: Explorations of Film and Anthropology. Chicago and London: The University of Chicago Press.

RYNKIEWICH, M. A. - SPRADLEY, J. P. (eds) (1976): Ethics and Anthropology: Dilemmas in Fieldwork. New York: John Wiley and Sons, Inc.

SAID, E. W. (1979): Orientalism. New York: Vintage Books.

SCHEPER-HUGHES, N. (1995): The Primacy of the Ethical: Propositions for a Militant Anthropology. In. Current Anthropology 36:3, pp. 409-20.

SIKORA, S. (2012): Film i paradoksy wizualności w antropologii. Praktikowanie antropologii. Warszawa: Wydawnictwo DiG.

SMITH, L. T. (1999): Decolonizing Methodologies: Research and Indigenous Peoples. London: Zed Books.

STRONG, P. T. (2012): American Indians and the American Imaginary: Cultural Representation Across the Centuries. Boulder, CO: Paradigm Publishers.

STRONG, P. T. (2004): Representational Practices. In. Thomas Biolsi (ed): A Companion to the Anthropology of North American Indians. Malden, MA and Oxford, UK: Blackwell Publishers, pp. 341-359.

ŠAVELKOVÁ, L. (2017): When the Creator's "Game" Spreads to the World. In: Barbora Půtová (ed): Identity, Tradition, and Revitalization of American Indian Cultures. Prague: Charles University, Karolinum Press, pp. 74-107.

TODOROVA, M. N. (1997, 2009): Imagining the Balkans. Oxford and New York: Oxford University Press. 
TÓTH, G. F. (2016): From Wounded Knee to Checkpoint Charlie: The Alliance for Sovereignty between American Indians and Central Europeans in the Late Cold War. Albany: SUNY.

TURNER, T. (1992): Defiant Images: The Kayapo Appropriation of Video. In. Anthropology Today 8:6, pp. 5-16.

VENNUM, Jr., T. (1994): American Indian Lacrosse: Little Brother of War. Washington and London: Smithsonian Institution Press.

VIZENOR, G. (1993). The Ruins of Representation: Shadow Survivance and the Literature of Dominance. In. American Indian Quarterly 17:1, pp. 7-30.

WEATHERFORD, E. (ed) (1981): Native Americans on Film and Video. New York: National Museum of the American Indian/Heye Foundation.

WEINBERGER, E. (1992): The Camera People. In. Transition 55, pp. 24-54.

WILSON, P. - STEWART, M. (eds.) (2008): Global Indigenous Media: Cultures, Poetics, and Politics. Durham and London: Duke University Press.

WOLFE, T. (2000): Cultures and communities in the anthropology of Eastern Europe and the former Soviet Union. In. Annual Review of Anthropology 29, pp. 195-216.

WOLFF, L. (1994): Inventing Eastern Europe. Stanford: Stanford University Press.

WORTH, S. - ADAIR, J. (1972). Through Navajo Eyes: An Exploration in Film Communication and Anthropology. Bloomington: The Indiana University Press. 